\title{
MAKNA LOGO PT. EIGERINDO MULTI PRODUK INDUSTRI (ANALISIS SEMIOTIKA CHARLES SANDERS PIERCE)
}

\author{
Ukon Furkon Sukanda, S.Sos.,M.Ikom \\ Reno Riando \\ ufsukanda@unis.ac.id \\ Prodi Ilmu Komunikasi, FISIP Universitas Islam Syekh Yusuf Tangerang
}

\begin{abstract}
ABSTRAK
Penelitian ini menggunakan analisis semiotika Charles Sanders Pierce membagi semiotika menjadi tiga elemen utama atau yang disebut sebagai segitiga makna atau triangle meaning antara lain: a) Tanda merupakan sesuatu yang berbentuk secara fisik yang dapat kita serap oleh panca indera manusia. b) Acuan tanda (objek) adalah konteks sosial yang dijadikan referensi sebuah tanda atau sesuatu yang ditunjuk oleh tanda. c) Pengguna tanda (interpretant) merupakan suatu konsep pemikiran yang menggunakan tanda serta menurunkan tanda ke suatu makna tertentu, segitiga makna tersebut dapat menggambarkan makna yang ada di dalam logo tersebut. Tipe penelitian yang digunakan adalah kualitatif yaitu metode deskriptif yang tepat digunakan untuk paradigma konstruktivisme.
\end{abstract}

Kata kunci : Makna logo, Eiger, Semiotika

\begin{abstract}
This research uses the analysis of the semiotics of Charles Sanders Pierce divides into three main elements of semiotics or the so-called triangle meaning or triangle meaning among other things: a) the sign is something physically shaped We can soak up the by the five senses of human beings. b) Reference marks (object) is the social context that made reference to a sign or something designated by the sign. c) users of the sign (interpretant) is a concept thought that use of the sign as well as lowering the mark to a particular meaning, the meaning of a triangle can depict the meaning that is in the logo. The type of research used the qualitative descriptive method is an appropriate use for the paradigm of Constructivism.
\end{abstract}

Key words: the meaning of the logo, the Eiger, Semiotics

\section{PENDAHULUAN}

"Logo merupakan identitas yang paling utama selain dari slogan, lagu dll. Hanya dengan melihat logo salah satu bisnis, kita bisa langsung mengenal organisasi bisnis tersebut dan mengetahui reputasinya. Pembuatan logo tampak seperti sederhana, namun tahukah anda seberapa keras team desainer logo yang mempersiapkan sebuah logo untuk pelanggannya? Sebuah tim desainer Corporate identity ketika tahap awal melakukan riset, tahap berikutnya melakukan penggalian ide utama serta visualisasi ide tersebut.

Langkah berikutnya mendesain sedemikian rupa sehingga didapat visual yang baik serta (mungkin) beberapa 
alternatif ide. Begitu panjangnya langkah tersebut hingga didapat identitas yang tepat untuk brand perusahaan tersebut. Oleh karena itu wajar bila biaya design Corporate identity cukup mahal (sebenarnya tidak, karena sebanding dengan output yang dihasilkan)".

"Simbol yang Penuh Makna di sini orisinalitas menjadi penting. Simbol tersebut tidak boleh sama atau menyerupai dengan simbol, warna dan makna pihak lain untuk menghindari image ganda atau bias di pikiran masyarakat. Biasanya kesederhanaan atau kompleksitas akan dapat menampilkan makna yang mendalam dan pesan yang disampaikan akan terbaca dengan jelas oleh masyarakat. Tidak ada aturan khusus mengenai bahwa simbol tersebut harus sederhana ataupun kompleks tetapi semuanya harus memiliki arti dan filosofis yang jelas".

"Logo dapat menjadi alat promosi dalam penjualan. Karena Corporate identity seperti salesman yang bekerja sepanjang waktu tanpa kenal lelah untuk memberikan image yang diingikan ke benak konsumen. Ia juga bertindak sebagai agen marketing atau petugas public relation yang handal dan cekatan. Walaupun masa kampanye suatu produk telah berakhir tetapi identitas tetap dipergunakan bertahun-tahun bahkan puluhan tahun dan diingat selalu oleh konsumen". "Peranan praktisi humas dalam sebuah organisasi lembaga atau perusahaan merupakan salah satukunci penting untuk pemahaman akan fungsi $P R$ dan komunikasi organisasi disamping sebagai sarana pengembangan, pencapaian profesion alitas dari praktisi humas. Praktisi humas juga di tuntut harus mampu mengetahui dan faham akan segala informasi terkini terlebih yang menyangkut organisasi, lembaga, atau Perusahaan tempat dia bekerja".

"Komunikasi merupakan kebutuhan integral dari sistem dan tatanan kehidupan sosial manusia atau masyarakat. Kehidupan manusia tidak dapat dilepaskan dari komunikasi, manusia akan selalau terlibat dengan komunikasi, aktivitas komunikasi dapat terlihat pada aspek kehidupan sehari - hari. arti komunikasi itu sendiri adalah merupakan sebuah proses penyampaian pesan dari komunikator kepada komunikan melalui saluran tertentu. Adapula yang menyebutkan komunikasi sebagai suatu proses penyampain pesan berupa lambang, pesan, suara, dan gambar dari suatu sumber kepada sasaran (audience) dengan menggunakan saluran tertentu. Hal ini dapat digambarkan melalui sebuah percakapan sebagai bentuk awal dari bentuk komunikasi. Orang yang sedang berbicara adalah source (sumber) dari komunikasi atau dengan istilah lain yang disebut dengan komunikator. Orang yang sedang mendengarkan disebut dengan audience, sasaran, pendengar atau komunikan. Apa yang sedang disampaikan oleh orang yang sedang berbicara disebut pesan, sedangkan saluran yang digunakan untuk menyampaikan dari komunikator ke komunikan disebut channel (saluran)".

"Seringkali kehadiran logo baru pada perusahaan banyak mengundan pro dan kontra baik dalam perusahaan maupun dalam luar perusahaan. Di mulai dari berbagai faktor di mana disebabkan oleh perbedaan persepsi mengenai segmentasi pasar atau mungkin dari segi kurangnya pemahanan latar belakang makna dari logo tersebut atau bahkan dari visi dan misi yang masih tidak sejalan. Meskipun demikian, sebuah logo didessain tentu demi keberlangsungan citra positif perusahaan 
baik dari dalam perusahaan itu sendiri maupun dari luar yaitu konsumen atau publik". "Melalui Citra baru tersebut diharapkan Eiger dapat memberikan sebuah pengalaman baru yang berbeda dari sebelumnya kepada stakeholders. Pengalaman baru tersebut adalah kualitas dari produk yang lebih baik dari produk mana pun yang pernah mereka kenal dan rasakan. Dengan mengubah identitas perusahaan, kadang - kadang perusahaan dapat mengubah atau memperbaiki citra mereka di masyarakat".

"Perubahan logo yang dilakukan PT. Eigerindo ini, secara langsung mengubah identitas dan citra perusahaan. Tugas seorang Public Relations dalam perusahaan yaitu untuk membangun citra positif perusahaan, dan hasil yang lebih baik dari sebelumya karena mendapatkan opini dan kritik dari masyarakat. mengingat dengan adanya perubahan untuk itu PT. Eigerindo kembali beradaptasi untuk menciptakan brand awareness kepada masyarakat mengenai tampilan PT. Eigerindo yang baru maka diperlukan mempertahankan adanya komunikasi timbal balik yang diperlukan dalam menangani, mengatasi masalah yang muncul, atau meminimalkan munlucnya masalah dengan adanya perubahan logo ini".

\section{TINJAUAN PUSTAKA}

\section{A. Tinjauan Teoritis}

\section{Teori Semiotika Charles Sanders Pierce}

"Dalam penelitian ini, teori yang digunakan peneliti adalah teori semiotika Charles Sanders Pierce. Menurut Eco dalam buku semiotika Alex Sobur pada tahun 2006 Secara etimologis, istilah semiotik berasal dari kata Yunani semeion yang berarti tanda. Tanda itu sendiri di definisikan sebagai sesuatu yang atas dasar konvensi sosial yang terbangun sebelumnya, dapat dianggap mewakili sesuatu yang lain.". "Menurut Littlejohn pada tahun (2005:35) semiotik adalah sebuah stimulus yang menandakan sesuatu di luar tanda itu sendiri. Dapat disimpulkan bahwa analisis semiotik merupakan cara untuk menganalisisdanmemberikan maknamakna terhadap lambanglambang yang terdapat suatu paket lambang-lambang pesan atau teks. Secara sederhana, semiotika merupakan suatu ilmu atau metode analisis untuk mengkaji tanda. Manusia dengan perantaraan tanda-tanda, dapat melakuka komunikasi dengan sesamanya. Tanda-tanda adalah perangkat yang kita pakai dalam upaya dalam berusaha mencari jalan di dunia ini, di tengah-tengah manusia dan bersama-sama manusia. Suatu tanda menandakan sesuatu selain dirinya sendiri, dan makna (meaning) ialah hubungan antara suatu objek atau ide dan suatu tanda".

"Semiosis menurut Charles Sanders Peirce adalah suatu hubungan antara tanda, objek, dan juga makna (a relationship among a sign, an object, and a meaning)".

"Menurut Charles Saunders

Pierce dalam Semiotika Komunikasi Tahun 2011 semiotika memiliki konsep yang menawarkan model dengan apa yang disebut triadic dan konsep trikonominya terbagi menjadi tiga", yakni sebagai berikut

\section{Represenstamen,}

\section{Object}

\section{Interpretant}




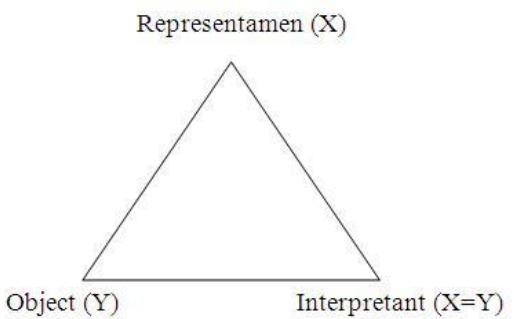

Gambar 1. Model Segitiga Makna Pierce (Marcel Danesi, 201

"Nawiroh pada tahun 2014 dalam

buku analisis semiotika Alex Sobur (2015) Masih pada gambar 2.1 Elemen Makna Pierce, bahwa objek merupakan sesuatu yang dirujuk oleh representament (tanda). Hal tersebut bisa berupa materi yang tertangkap panca-indera atau juga bersfat mental dan imajiner. Sedangkan interpretant merupakan sebuah tanda yang ada dalam benak seseorang tentang objek yang dirujuk tanda $(\mathrm{X}=\mathrm{Y})$. Apabila ke-tiga elemen makna itu berinteraksi dalam benak sesorang, maka muncullah makna tentang sesuatu yang diwakili oleh tanda tersebut".

\section{B. Landasan Konseptual}

\section{Identitas Visual}

"Menurut Rustan Tahun 2010 Identitas visual adalah identitas yang berkaitan dengan citra atau image yang dipertahankan oleh perusahaan atau entitas lain sebagai jembatan untuk menyatukan berbagai konteks, audience, bagi perusahaan tersebut . simbolisasi ciri khas yang mengandung diferensial dan mewakili citra organisasi, Identitas dapat berasal dari sejarah, filosofi, visi/cita-cita, misi/fungsi, tujuan, strategi atau program. Dalam perancangan ini obyek entitas adalah sebuah brand Eiger. Secara sederhana identitas visual terdiri dari beberapa elemen atau atribut di dalamnya, mulai dari pemilihan nama sebagai langkah awal, logo, tipografi, warna khas, serta images atau elemen gambar pendukung yang termasuk disini adalah foto, artworks, infographics". "Effendy Tahun 1989 menjelaskan bahwa Identitas Visual yang dirancang juga diaplikasikan dalam media promosi, pengertian media merupakan perantara atau wahana penyalur pesan atau informasi kepada orang lain. Media adalah sarana yang dipergunakan komunikator sebagai saluran untuk menyampaikan suatu pesan kepada komunikan, apabila komunikan jauh atau banyak jumlahnya , atau kedua-duanya. Penjelasan Morrisan tahun 2010 Promosi adalah suatu kegiatan untuk meningkatkan penjualan barang atau jasa. Sedangkan promosi dapat diartikan sebagai kegiatan komunikasi untuk meningkatkan volume penjualan dengan usaha-usaha yang bersifat persuasif dalam menawarkan barang atau jasa. Ditambah lagi menurut Michael Ray yang dikutip oleh Morrisan (2010:16) mendefinisikan promosi sebagai koordinasi dari seluruh upaya yang dimulai oleh pihak penjual untuk membangunberbaga saluran informasi dan persuasi untuk menjual barang dan jasa atau memperkenalkan suatu gagasan. Jadi secara garis besar media promosi dapat diartikan alat atau sarana yang digunakan untuk meningkatkan penjualan barang dan jasa atau memperkenalkan suatu gagasan".

\section{Logo}

"Logo menggunakan bentuk picture mark sekaligus letter mark dimana elemen gambar dan tulisan saling 
berbaur satu sama lain yang dapat menjadikan sebuah produk dari perusahaan mempunyai ciri khasnya sendiri".

\section{Picture Mark}

"Merupakanidentitas yang digunakan untuk menggambarkan citra dan karakter suatu lembaga atau perusahaan maupun organisasi”.

\section{Letter Mark}

"Logo ini biasanya terdiri dari huruf depan nama perusahaan dan tidak lebih dari 3 huruf dan didesign secara stylize yang dapat mewakili organisasi tersebut".

\section{Tag Line}

"Teks pendek yang berfungsi untuk memperjelas pemikiran, atau dirancang dengan bentuk, efek dramatis. Banyak slogan tagline yang merupakan ungkapan yang dikaitkan dengan individu, kelompok sosial, atau produk".

\section{Arti Warna}

"Aspek warna sangat penting karena dapat memberikan kontrubusi yang cukup besar terhadap pembentukan persepsi dan citra perusahaan dibenak khalayak, selain itu warna juga meliliki efek-efek psikologis manusia. Aspek warna dalam elemen logo memaikan peran yang sangat besar pada keputusan pembelian walau itu didasari atau tidak. Warga juga meningkatkan brand recognition sebesar 50\%, menurut penelitian yang dilakukan oleh University of Loyola, Chicago, Amerika. Karena itu pemilihan warna yang tepat merupakan proses yang sangat penting dalam mendesain identitas visual. Untuk itu dbutuhkan riset yang mendalam menyangkut beberapa bidang, antara lain psikologi, budaya dan komunikasi”.

\section{Konsep Visual}

"Dalam konsep tata desain ini lebih ditekankan pada identitas, karakter, ciri khas dan keunikan yang dimiliki oleh Perusahaan Eiger, yaitu produk kerajinan dengan level internasional, suasana religius dengan kegiatan dan prestasi nasional, serta produk pertanian yang termasuk varietas unggul nasional".

\section{Corporate}

\section{Identity}

"Identitas perusahaan adalah strategi utama bagi semua perusahaan menuju representasi eksternal dan internal yang meyakinkan, konsisten serta harmonis dari perusahaan tersebut. Analisis terhadap status quo statu perusahaan mengungkapkan semua hal yang terlah dicapai sebegitu jauh, dan pada tingkatan apakah sasaran masa lalu telah dicapai".

\section{Corporate Image}

"Corporate image terbentuk dari kontak perusahaan yang enginterpretasikan informasi mengenai informasi mengenai perusahaan. Corporate Image adalah sautu perusahaan yang dipersepsikan dan dilihat oleh masyarakat atau publik baik Stakeholder maupun Stockholder perusahaan. informasi ini biasanya didapatkan dari produk maupun dari iklan dari perusahaan tersebut".

\section{METODOLOGI PENELITIAN}


"Pada penelitin kali ini, paradigm yang digunakan mengacu pada paradigma konstruktivisme. Paradigma konstruktivisme berbasis pada pemikiran umum tentang teori-teori yang dihasilkan oleh peneliti dan teoritis aliran konstruktivis. Little John mengatakan bahwa teori-teori aliran kontruktivis berlandasan pada ide bahwa realitas bukanlah bentukan objektif, tetapi dikonstruksikan melali proses interaksi dalam kelompok, masyarakat, dan budaya".

"Penelitian ini menggunakan metode kualitatif, Menurut Bogdan dan Taylor dalam buku Cresswell penelitian kualitatif adalah salah satu jenis penelitian yang proses penelitiannya menghasilkan data deskriptif dari sesuatu yang diteliti. Penelitian kualtitatif merupakan metode metode untuk mengeksplorasi dan memahami makna yang oleh sejumlah individu atau sekelompok orang dianggap berasal dari masalah sosial atau kemanusiaan".

\section{PEMBAHASAN}

"Eiger menjadi salah satu brand produsen penyedia produk outdoor terbesar di Indonesia yang awalnya hanya menyediakan untuk kaum pria dan sekarang bertransformasi bukan hanya untuk pria melainkan untuk perempuan sesuai dengan perubahan yang dilakukan mereka terhadap logo serta tagline mereka”.

"Pemaparan dalam Logo Eiger ini dianalisis dengan menggunakan teknik semiotika Charle Sandeurs Pierce". Teknik ini terdiri dari :

1) Ikon adalah tanda dirancang

untuk merepresentasikan sumber acuan,melalui simulasi atau persamaan (artinya, sumber acuan dapat dilihat, didengar, dan seterusnya, dalam ikon.

2) Indeks adalah tanda dirancang untuk engindikasikan sumber acuan atau saling menghubungkan sumber acuan.

3) Simbol adalah tanda dirancang untuk menyandikan sumber acuan melalui kesepakatan."Pemaparan yang telah peneliti pilih merupakan gambaran yang merepresentasikan Logo Eiger. Menurut Langer menyebutkan bahwa salah satu kebutuhan pokok manusia adalah kebutuhan simbolisasi atau penggunaan lambang. Kemampuan manusia dalam menggunakan simbol, menurut Wieman dan Walter merupakan salah satu sifat dasar dari mahluk manusia. Saat ini peranan simbol visual sebagai bentuk komunikasi sangatlah penting mengingat keberadaannya sangat tak terbatas dalam kehidupan kita seharihari. Logo merupakan bagian dari identitas perusahaan yang dirancang terutama sebagai simbol pembeda untuk dikenali di antara perusahaan-perusahaan lainnya, sebagai bentuk komunikasi yang mencerminkan nilai-nilai ideal suatu perusahaan yang sengaja dibentuk, dan memainkan peran yang sangat penting dalam benak konsumen, khususnya peran dalam menciptakan persepsi yang kuat tentang merek atau perusahaan, serta mempunyai arti penting karena dapat mengingatkan khalayak akan perusahaan tersebut (Anggoro, 2001 : 280)".

"Representasi yang muncul dari logo baru Eiger ini adalah hasil dari apa yang ditangkap oleh masyarakt yang melihat Logo terbaru dari Eiger itu sendiri karena bisa diniai dari perbedaan yang memang sudah menyolok sekali 
lihat logo dari Eiger itu sendiri, Maksutnya adalah apakah yang ditangkap masyarakat yang melihat itu sesuai atau jika tidak apakah yang ditangkap oleh masyarakat dari logo terbaru Eiger itu sendiri”.

“Objek yang digunakan meski sebenarnya tidak berubah yaitu bentuk dari pengununngan di Swiss, namun pemaknaan yang berubah karena penggunaan warna yang berbeda itu menjadikan pemaknan pun akan berbeda dari sebelumnya. Dengan begitu penilaian dengan logo baru itu bisa diartikan apa saja tergantung pada cara masyarakat memandang logo baru itu sendiri yang berubah secara signifikan”.

"Interpretasi, makna dari logo terbaru ini berubah total mulai dari pemaknaan bentuk, warna, tagline serta tujuan perubahaan itu sendiri yang diusung oleh Eiger sendiri. Logo yang baru ini membawa nuansa baru serta suasana yang jauh lebih ceria dalam pemaknaannya itu sendiri ketimbang logo lama dari Eiger".

\section{KESIMPULAN}

Berdasarkan analisis Semiotika Charles Sanders Pierce yang digunakan pada penelitian ini untuk mengungkap makna logo Eiger melalui tanda tanda yang terdapat pada logo tersebut, maka dapat disimpulkan sebagai berikut :

\section{Logo baru dari Eiger memiliki}

ide pada semiotika yang menampilkan unsur produk dan nama perusahaan yang memiliki hubungan atau ikatan kuat satu sama lainnya.

2. Selain itu, $\operatorname{logo}$ tersebut juga memiliki elemen komunikasi yang diantaranya ialah, arti dari warnawarna yang digunakan oleh Eiger itu sendiri. Warna-warna tersebut mewakili perubahan yang dilakukan terhadap logo itu sendiri.

3. Dari hasil makna berdasarkan teori semiotika yang telah dianalisis, $\log$ tersebut menghasilkan beberapa makna, yaitu : Menggambarkan sesuatu yang berkelas dan menunjukan asa untuk selalu menjadi lebih baik dalam memberi pelayanan serta menunjukan komitmen untuk memproduksi produk berkualitas yang dipersiapkan secara khusus untuk memenuhi kebutuhan kegiatan alam consume mereka. Pencerminan karakter menjadi pemegang kendali kuat yang mampu meberikan kenyamanan dan keaman kepada para

konsumennya, dengan tampilan baru yang fresh sehingga menghasilkan hal positif yang penuh motivasi dan semangat baru bagi konsumennya dalam berkegiatan alam dengan menyenangkan.

\section{SARAN}

Saran yang dapat peneliti berikan dari penelitian skripsi ini yang terkait dengan Makna Logo

PT.Eigerindo Multi Produk Industri adalah sebagai berikut : 
1. Secara akademis, untuk

penelitian selanjutnya diharapkan dapat lebih memahami logo dan semiotic yang lebih mendalam sehingga dalam menganalisa akan dapat menghasilkan data yang akurat.

2 Secara Praktis, kepada brand yang membuat logo nya, untuk dapat menyampaikan pesan yang dikomunikasikan logo melalui cara yang menarik agar khalayak atau konsumen memperoleh memori yang kuat terhadap brand teserbut.

\section{DAFTAR PUSTAKA}

Adamsmorioka. (2004). Logo Design Workbook. USA: Rockport Publishers

Barker, Chris. 2004. Cultural Studies: Teori dan Praktek. Yogyakarta: Kreasi Wacana.

Bogdan, Biklen. 1982. Pengantar Studi Penelitian. Bandung : PT ALFABETA

Bogdan dan Taylor. 1975. Dalam J. Moleong, Lexy. 1989. Metodologi Penelitian Kualitatif.

Bandung : Ramadja Karya.

Budiman, Kris. 2011. Semiotika Visual

(Konsep, Isu dan

Problem Ikonisitas). Yogyakarta :

Percetakan Jalasutra.

Creswell, John. 2009. RESEARCH DESIGN Pendekatan Kualitatif, Kuantitatif, dan Mixed. Yogyakarta : Pustaka Pelajar.
Danesi, Marcel. 2010. Pesan, Tanda, dan Makna: Buku Teks Dasar Mengenai Semiotika dan

Teori Komunikasi. Yogyakarta: Jalasutra.

Eco, Umberto. 2011.Teori Semiotika: Signifikasi Komunikasi, Teori Kode, serta Teori

Produksi-Tanda.Yogyakarta: Kreasi Wacana.

Kusmiati R., Artini. 1999. Teori Dasar DESAIN KOMUNIKASI VISUAL. Jakarta: Djambatan.

Rustan, Surianto. 2009. Mendesign Logo. Jakarta: PT. Gramedia Pusaka Utama.

Soemanagara, 2008. Strategic Marketing Communication. Bandung: Alfabeta.

Sutojo, Siswanto. 2004. Membangun Citra Perusahaan . Jakarta: PT. Damar Mulia Pustaka. Tinarbuko, Sumbo. 2009. Semiotika Komunikasi Visual. Yogyakarta: Jalasutra. Wibowo, Indiwan Seto Wahyu. 2013. Semiotika Komunikasi. Edisi ke-2. Jakarta: Mitra Wacana Media.

Ardianto, Elvinaro. 2011. Hand Book of Public Relations. Bandung: Remaja Rosdakarya.

Anggoro, M.Linggar. 2001. Teori dan Profesi Kehumasan. Jakarta: Bumi Aksara.

Kasali, Rhenald. 2003. Manajemen Public Relations Konsep dan 
Aplikasinya di Indonesia. Jakarta: Pustaka Utama Grafiti.

Fiske, John. 2012. Pengantar Ilmu

Komunikasi edisi ketiga. Jakarta: Rajagrafindo Persada.

Littlejohn, Stephen W. Dan Karen A.

Foss.2009. Teori Komunikasi.

Penerjemah Mohammad Yusuf

Hamdan. Jakarta : Salemba

Humaika.

Sobur, Alex. 2002. Analisis Teks Media:

Suatu Pengantar Untuk Analisis Wacana, Analisis Semiotik, dan Analisis Framing. Bandung: Remaja Rosda Karya.
Vera, Nawiroh. 2014. Semiotika Dalam Riset Komunikasi. Bogor : Ghalia Indonesia.

Wibowo, Indriawan Setyo Wahyu. 2011. Semiotika Komunikasi. Jakarta: Mitra Wacana Media.

\section{Sumber Lain}

http://repository.unpas.ac.id/12613/ http://eprints.undip.ac.id/26695/1/Skripsi Kartika Mandasari C2A606057(r).p df 